\title{
PLEISTOCENE ICE AT THE BASE OF THE BARNES ICE CAP, BAFFIN ISLAND, N.W.T., CANADA
}

\author{
(Department of Geology and Geophysics, University of Minnesota, Minneapolis, \\ Minnesota 55455, U.S.A.)
}

\begin{abstract}
Oxygen-isotope ratios indicate that a distinctive band of white ice along the margin of the Barnes Ice Cap is of Pleistocene age. It is estimated from a flow model that beneath the center of the ice cap the thickness of the band should be about 0.6 times its thickness at the margin, or about $8 \mathrm{~m}$. However, an independent estimate, based on calculated vertical strain-rates and explicitly assuming no basal melting, predicts a thickness of about $22 \mathrm{~m}$ beneath the center of the ice cap. The discrepancy between the two thickness estimates is interpreted as indicating that basal melting has occurred. Calculated basal temperatures support this conclusion.

Résumé. Glaces fossiles du Pleistocène à la base de la Barnes Ice Cap, Ile de Baffin, Territoire du N.O., Canada. Par le taux d'oxygène 18 , on prouve qu'une couche distincte de glace blanche en bordure de la Barnes Ice Cap, date de l'époque Pleistocène. Se basant sur un modèle des glaces d'écoulement, on estime que l'épaisseur de la couche, au centre de la calotte, doit être o,6 fois celle des bords, soit $8 \mathrm{~m}$ environ. Cependant, une autre estimation, basée sur le calcul des contraintes verticales et laissant de coté la fonte au sol, prévoit une épaisseur de l'ordre de $22 \mathrm{~m}$ sous le centre de la calotte glaciaire. La discordance entre ces deux épaisseurs est interprêtée comme la preuve de la fonte au sol. Les températures calculées au niveau du socle renforcent cette conclusion.

Zusammenfassung. Pleistozänes Eis am Grunde des Barnes Ice Cap, Baffin Island, N.W.T., Kanada. Aus den Verhältnissen von Sauerstoffisotopen geht hervor, dass ein bezeichnendes Band weissen Eises längs des Randes des Barnes Ice Cap pleistozänes Alter besitzt. Aus einem Fliessmodell lässt sich abschätzen, dass unter dem Zentrum des Eisschildes die Dicke des Bandes etwa das o,6-fache der randlichen Dicke, also etwa $8 \mathrm{~m}$, aufweisen sollte. Eine unabhängige Schätzung jedoch, die auf berechneten vertikalen Spannungsraten beruht und ausdrücklich kein Schmelzen am Untergrund annimmt, kommt auf eine Dicke von etwa $22 \mathrm{~m}$ unter dem Zentrum des Eisschildes. Die Diskrepanz zwischen den beiden Dickenschätzungen lässt sich durch die Annahme von Schmelzvorgängen am Untergrund beseitigen. Die berechneten Temperaturen am Untergrund bestätigen diese folgerung.
\end{abstract}

\section{INTRODUCTION}

Studies of the isotopic composition of ice cores from Camp Century, Greenland, and "Byrd" station, Antarctica, show that the lowest several hundred meters of ice in these ice sheets is of Pleistocene age (Dansgaard and Johnsen, I969; Dansgaard and others, I969; Epstein and others, 1970). The Pleistocene ice is characterized by $\delta^{18} \mathrm{O}$ values which are $6 \%$ ("Byrd" station) to I $3 \%$ (Camp Century) lower than in post-Pleistocene ice.

Calculations suggest that there should be several meters of Pleistocene ice at the base of the Barnes Ice Cap also, if the rate of basal melting has been low or negligible in postPleistocene time, and studies of the isotopic composition of basal ice exposed near the margin of the ice cap indicate that Pleistocene ice is indeed present.* It is the purpose of this paper to present the isotopic data in greater detail than previously, and to consider the thermal history of the ice cap in the light of these data.

\section{ISOTOPIG COMPOSITION AND RELATION TO STRUCTURE}

Along the margin of the south dome of the Barnes Ice Cap there is a prominent band of white ice which is both underlain and overlain by bluish-gray ice (Figs. I and 2). $\delta^{18} \mathrm{O}$ values are $-23 \%$ to $-26 \%$ in the blue ice and $-38 \%$ to $-40 \%$ in the white ice (Fig. 2). The values in the blue ice are comparable to those from a core from the Meighen Ice Cap and also to those from the upper part of the Camp Century core, and the three values in the

* Preliminary $\delta^{18} \mathrm{O}$ values published previously (Hooke, $1973[\mathrm{a}]$ ) were $4 \%$ too negative due to a calculation error by the laboratory in which the analyses were made. 
white ice are comparable to those from the lower parts of both the Camp Century and "Byrd" cores (Table I). Two additional values from the white ice, not published here due to their lower accuracy, are consistent with the three shown in Figure 2.

The $\delta^{18} \mathrm{O}$ shifts of about $11 \%$ in the Camp Century core and $6 \%$ in the "Byrd" core (Table I) have been attributed to the change from Pleistocene to post-Pleistocene climatic conditions about 12 ooo years ago. The shift of about $14 \%$ on the Barnes Ice Cap is also attributed to this climatic change; the white ice is thus presumed to be of Pleistocene agə

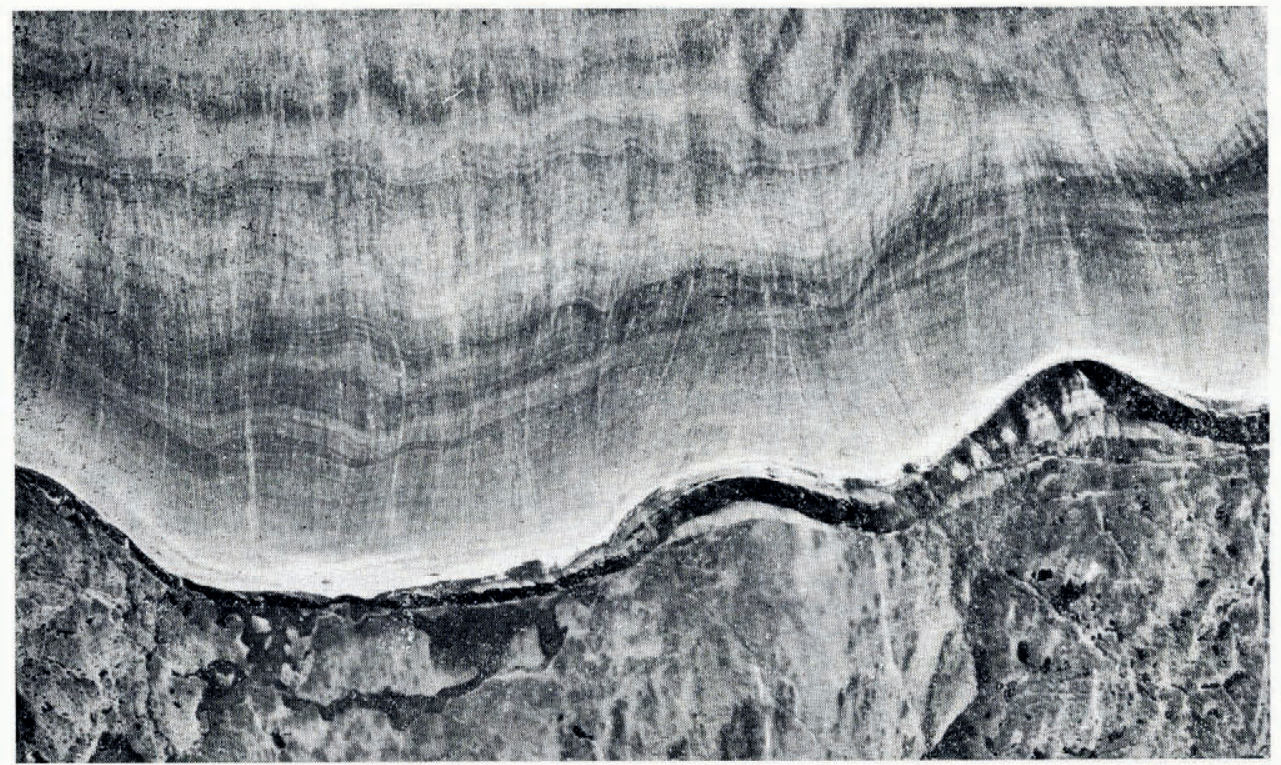

Fig. I. Air photograph of a section of the south dome of the Barnes Ice Cap, showing the white ice band near the margin. (Photograph number A-I 7043-(63), National Photo Library, Department of Energy, Mines, and Resources, Ottawa, Canada.)

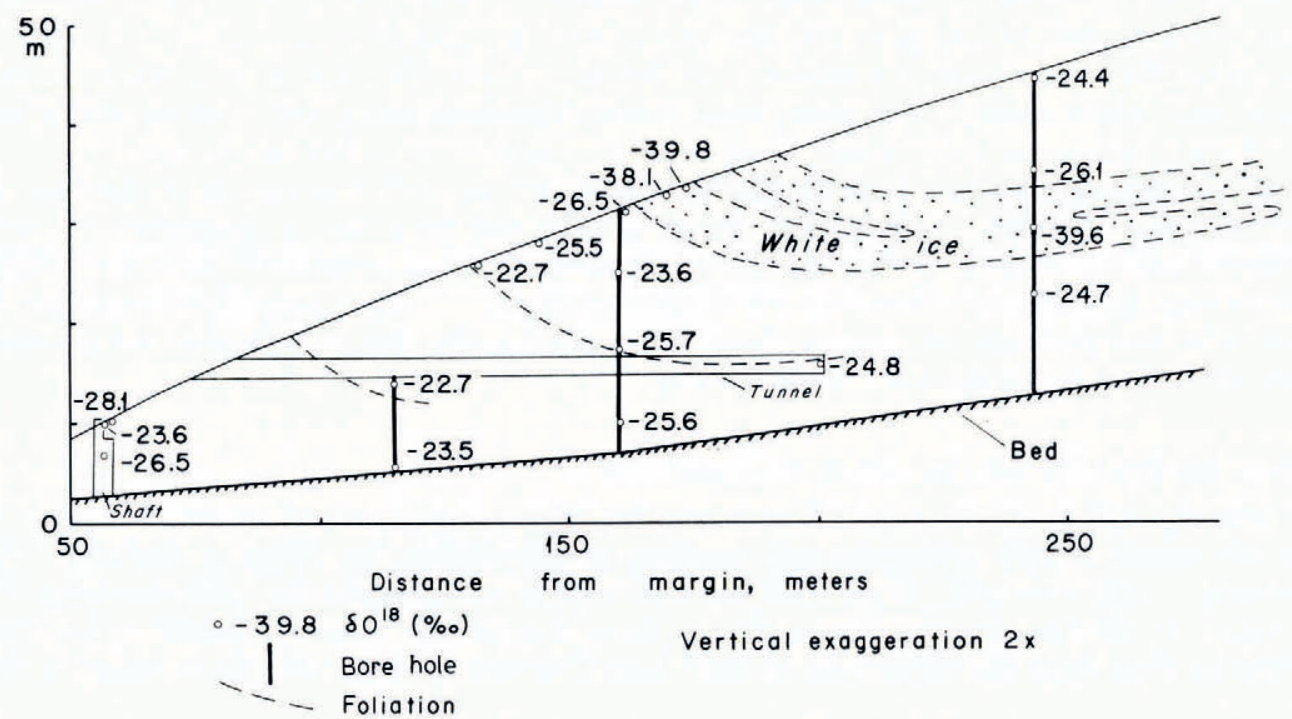

Fig. 2. Relationship between structure and isotopic composition in the margin of the Barnes Ice Cap. Isotopic compositions are given as the relative deviation, $\delta^{18} \mathrm{O}$, in per mille, of the ${ }^{18} \mathrm{O} /{ }^{16} \mathrm{O}$ ratio from that of Standard Mean Ocean Water. 
TABle I. Comparison of $\delta^{18} \mathrm{O}$ values in Various ICE SheEts and ICE CAPS

\begin{tabular}{|c|c|c|c|c|c|}
\hline $\begin{array}{l}\text { Location and } \\
\text { present surface } \\
\quad \text { elevation }\end{array}$ & $\begin{array}{c}\delta^{18} O \text { in } \\
\text { post-Pleistocene } \\
\text { ice } \\
\% \\
\%\end{array}$ & $\begin{array}{l}\delta^{18} \mathrm{O} \text { in } \\
\text { Pleistocene } \\
\quad \text { ice } \\
\% \\
\%\end{array}$ & $\begin{array}{c}\delta^{18} \mathrm{O} \\
\text { shift } \\
\%\end{array}$ & $\begin{array}{c}\text { Depth to } \\
\text { Pleistocene- } \\
\text { post-Pleistocene boundary } \\
\mathrm{m}\end{array}$ & Reference \\
\hline $\begin{array}{l}\text { Camp Century } \\
\quad(\text { I } 900 \mathrm{~m})\end{array}$ & -29 & -40 & II & I 100 & Dansgaard and Johnsen, 1969 \\
\hline $\begin{array}{l}\text { "Byrd" station } \\
\text { ( } 1500 \mathrm{~m} \text { ) }\end{array}$ & -34 & -40 & 6 & I 200 & Epstein and others, $197^{\circ}$ \\
\hline $\begin{array}{l}\text { Meighen Ice Cap } \\
\quad(260 \mathrm{~m})\end{array}$ & $-2 \mathrm{I}$ & Not present & 一 & 一 & Koerner and others, 1973 \\
\hline $\begin{array}{l}\text { Barnes Ice Cap } \\
\quad(600 \mathrm{~m})\end{array}$ & -25 & -39 & I4 & 425 & \\
\hline
\end{tabular}

and the overlying blue ice of post-Pleistocene age. The slightly greater $\delta^{18} \mathrm{O}$ shift on the Barnes Ice Cap, in comparison particularly with the shift in the Camp Century core, may reflect fractionation during periods of summer melt in post-Pleistocene time on the former. The high (less negative) $\delta^{18} \mathrm{O}$ values $(-20 \%$ to $-22 \%$ ) from the Meighen core have been attributed to such fractionation (Koerner and others, 1973). The similarity among the $\delta^{18} \mathrm{O}$ values for Pleistocene ice in the Camp Century, "Byrd" station and Barnes Ice Cap samples is unexpected, and may imply that the accumulation region for the latter ice on the Laurentide ice sheet was comparable in elevation to the accumulation regions for the Pleistocene ice at Camp Century and "Byrd" station.

The white ice band owes its color to a high concentration of air bubbles. In addition to their effect on the color of the ice, these bubbles also reduce the bulk density of the ice to $0.87 \mathrm{Mg} / \mathrm{m}^{3}$ (compared with $0.9^{2}$ in the blue ice) and increase its rate of deformation by about $50 \%$ (Hooke, I $973[\mathrm{~b}]$ ).

The lower bubble content of the overlying blue ice probably reflects an increase in the amount of percolating melt water in the accumulation zone in post-Pleistocene time. Most of the accumulation on the Barnes Ice Cap at present is in the form of superimposed ice, or

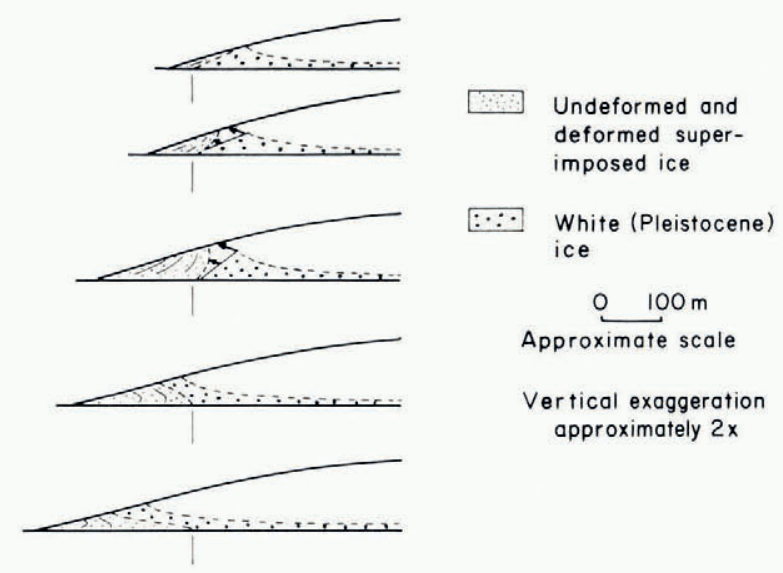

Fig. 3. Sequential cross-sections showing schematically, from top down, the process by which superimposed ice is believed to be over-ridden during an advance of the glacier. Such over-riding occurs if the glacier is frozen to its bed, because velocity increases with height above the bed. Light solid lines in superimposed ice depict schematically the progressive overturning of original sedimentary banding. In nature such banding is commonly obscuret by development of foliation in later stages of deformation (Hooke, 1973[a]). 
ice formed by refreezing of percolating melt water. Such melt water can displace air that otherwise might become trapped during compaction of snow into firn and thence ice.

The blue ice beneath the white ice is also presumed to be of post-Pleistocene age. The reversal of normal stratigraphic order results because this blue ice is superimposed ice which formed along the margin and which was subsequently over-ridden by the white ice during an advance of the glacier (Hooke, I973[a]). The superimposed ice forms beneath wind-drift snow which accumulates along the margin, and which, due to its greater thickness, often persists through the ablation season. The over-riding process does not involve thrusting of the Pleistocene ice over the marginal superimposed ice along a discrete shear zone; rather, the Pleistocene ice and the underlying superimposed ice both deform (Fig. 3), with shear strainrates being somewhat higher in the white ice, but only due to its higher bubble concentration.

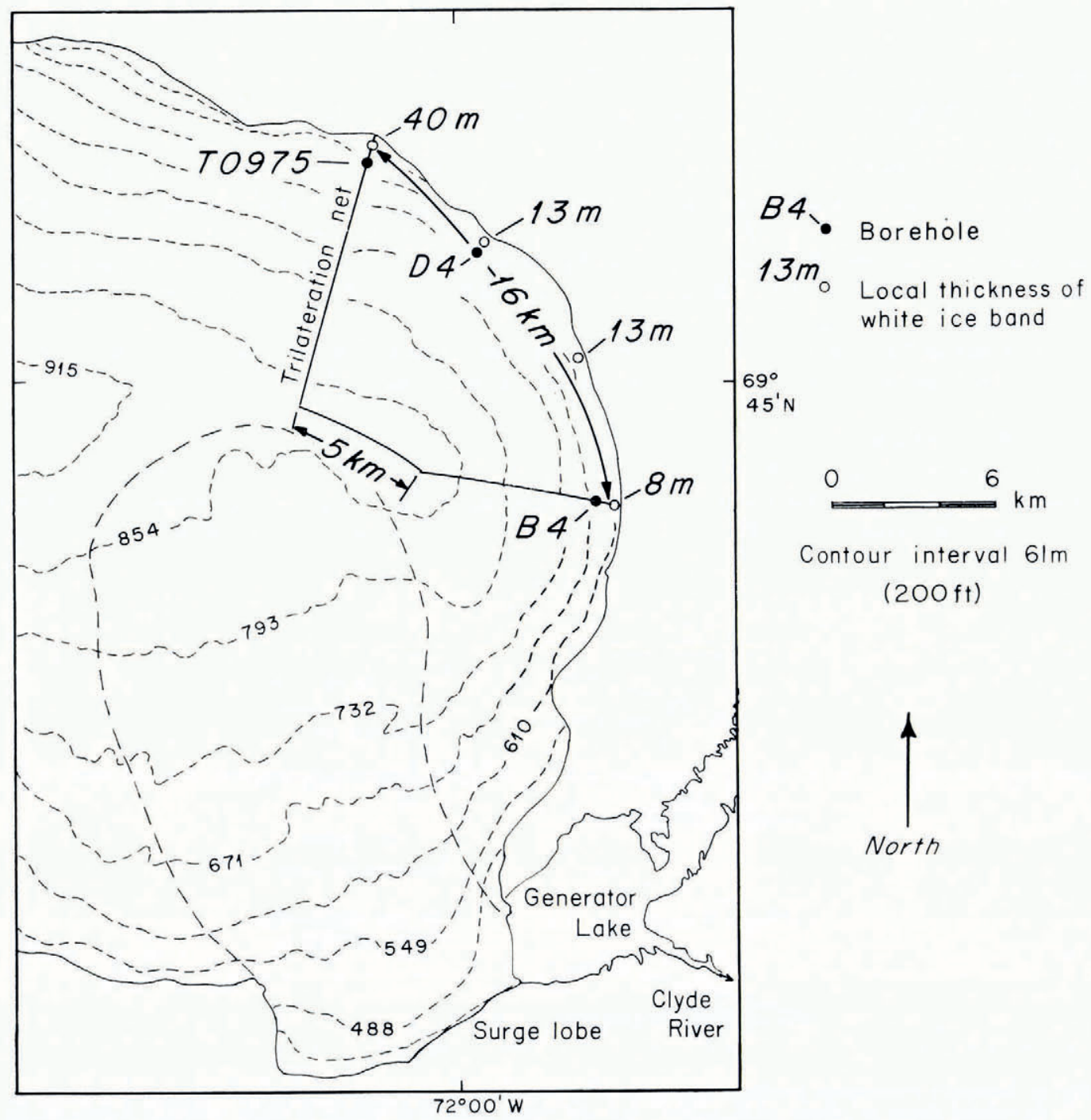

Fig. 4. Map of the south dome of the Barnes Ice Cap showing the area considered in calculating thickness of white ice band beneath center of ice cap and thickness of this band at four locations near the margin. Approximate area of surge enclosed by dashed line (Holdsworth, 1973). 
Both the upper and lower contacts of the white ice are sharp. Above the upper contact there are commonly $\mathrm{I}$ or $2 \mathrm{~m}$ of light blue ice, which grade upward into the darker bluish-gray ice. Below the lower contact the upper few meters of bluish-gray ice commonly contain englacial debris. Such debris occurs only rarely in or above the white ice. Along many sections of the margin this debris gives rise to ice-cored moraines (Fig. I).

When viewed on a broader scale, the upper boundary of the white ice band is locally ragged, with white folia $5^{-1} 5 \mathrm{~m}$ wide diverging from the main band and continuing parallel to it for a few hundred meters before grading into blue ice along strike (Fig. I). Detailed study has revealed that many, if not all, of these diverging bands are recumbent isoclinal folds (Fig. 2). Hudleston (in press) has shown that such folds may form when minor advances or retreats of a glacier change the pattern of flow lines over irregularities in the bed.

\section{Thigkness of Pleistocene ice}

The thickness of the white ice band was determined at four points along the margin (Fig. 4) from accurate measurements of the up-glacier dip of the band, its outcrop width and the slope of the glacier surface. An additional estimate was obtained from deformation measurements in the up-glacier bore hole shown in Figure 2 (Hooke, 1973[b]). The thickness averages about $13 \mathrm{~m}$ over most of the area studied, but it reaches approximately $40 \mathrm{~m}$ in the north-west corner of this area.

The remarkable continuity and relatively uniform thickness of the white ice band along the margin permit an estimate of the thickness of Pleistocene ice beneath the center of the ice cap. By comparing the thickness thus obtained with the thickness calculated from Philberth and Federer's (1971) vertical strain-rate model, which assumes that there has been no melting at the base, one can estimate by difference the amount of such basal melting in postPleistocene time.

To calculate the thickness of the white ice band beneath the center of the ice cap, consider two vertical columns of ice extending through the glacier. At the end of the Pleistocene the tops of these two columns are at $\mathrm{A}$ and $\mathrm{B}$ in Figure 5 . We assume that the horizontal velocity is independent of depth and that ice is incompressible. Thus as the columns move outward they become shorter and fatter, so to speak, without bending. We assume further that we are dealing with an idealized perfectly plastic ice cap with a surface profile

$$
h=(c x)^{\frac{1}{2}}
$$

where $h$ is the height of the surface a distance $x$ from the margin, and $c$ is a constant that depends on the yield strength of the ice (Nye, I95I, p. 57 I). Finally, we assume that the ice cap has not changed shape since the end of the Pleistocene, and that it has had a balanced mass budget during this time. The effect of these assumptions on the calculations will be discussed more fully below.

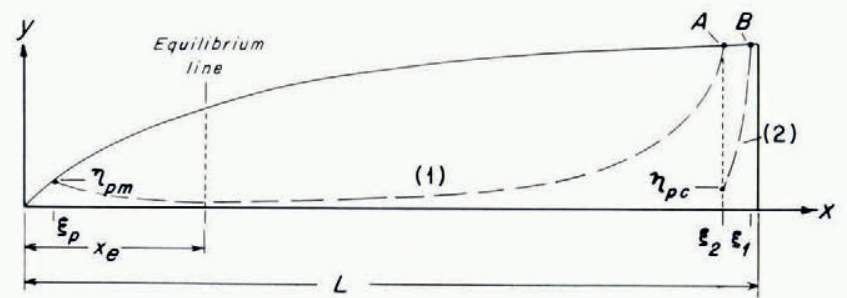

Fig. 5. Coordinate axes and flow paths used in calculation of relative thickness of Pleistocene ice beneath center of ice cap. Surface profile and paths are schematic only. 
We now follow points $\mathrm{A}$ and в as they move outward and are progressively buried by postPleistocene accumulation. The $x$ and $y$ coordinates of these points will be denoted $x=\xi(t)$ and $y=\eta(t)$, where $(t)$ indicates that the coordinates are a function of time. Thus at any time $t$ the column will be a distance $\xi$ from the margin and will have a height $\eta$. $\eta$ is, therefore, the thickness of Pleistocene ice at this time and distance from the margin.

Specifically we determine the present thickness of Pleistocene ice near the margin, $\eta_{\mathrm{pm}}$, and near the center $\eta_{\text {pc }}$. In calculating $\eta_{\mathrm{pm}}$, transverse strain is included by multiplying by $\frac{5}{16}$ (Fig. 4). Because the decrease in horizontal velocity with depth has been ignored, we know that both $\eta_{\text {pc }}$ and $\eta_{\text {pm }}$ will be grossly underestimated by this approach (compare, for example, Dansgaard and Johnsen ( I 969) with Philberth and Federer (I 97I)). However, because the paths of both points involve similar amounts of time close to the bed, the ratio $\eta_{\mathrm{pc}} / \eta_{\mathrm{pm}}$ will be much less affected by this assumption. We therefore estimate the thickness of Pleistocene ice beneath the center of the ice cap by multiplying the observed thickness at the margin by this ratio.

To derive equations for the paths of points $\mathrm{A}$ and $\mathrm{B}$, we first write the horizontal velocity as $u(x)=-\frac{\mathrm{I}}{h} \int_{x}^{L} A \mathrm{~d} x$ where $A(x)$ is the accumulation rate. In the ablation zone the appropriate relation is $u(x)=-\frac{\mathrm{I}}{h} \int_{0}^{x} A_{\mathrm{b}} \mathrm{d} x$ where $A_{\mathrm{b}}(x)$ is the ablation rate. The minus sign indicates that flow is in the $-x$ direction (Fig. 5). The vertical velocity, $v$, is then obtained from the condition of incompressibility, $\frac{\partial u}{\partial x}+\frac{\partial v}{\partial y}=0$ by differentiating $u$ with respect to $x$ and integrating with respect to $y$. The boundary condition $v=0$ on $y=0$ is used. The time, $t$, required for an element of ice to travel from some point a distance $\xi_{0}$ from the margin to a point a distance $\xi$ from the margin is obtained by integrating $\mathrm{d} t=\mathrm{d} \xi / u$. Because the velocity is independent of depth, $t$ is independent of $\eta_{0}$, the $y$ coordinate of the element at $t=0$. Finally, the path is obtained by integrating $\mathrm{d} \xi / u=\mathrm{d} \eta / v$. The approach is basically that used by Hooke (1973[b]), and earlier by Nielsen and Stockton (1956). The resulting equations are presented in Table II.

Two models for the variation of $A$ and $A_{\mathrm{b}}$ with $x$ are considered (Table II). In the first, $A$ and $A_{\mathrm{b}}$ are assumed to be independent of $x$, and in the second $A$ and $A_{\mathrm{b}}$ increase linearly from zero at the equilibrium line to maxima at the divide and margin, respectively. The second model is clearly more realistic and, in fact, gives horizontal velocities that are in reasonable agreement with measured velocities on the trilateration net, a series of 12 overlapping strain nets extending from the divide to the margin (Holdsworth, 1973, personal communication, December 1973). However, this model leads to unpleasant expressions for the time and for the path in the accumulation zone (Table II). These expressions might be evaluated analytically, but for the present it is easier to integrate them numerically.

As observed previously (Hooke, I973[b]), foliation bands increase in thickness fairly rapidly toward the margin (Fig. 2) because the longitudinal strain-rate becomes increasingly compressive. Thus proper choice of $\xi_{\mathrm{p}}$, the present distance of the band from the margin, is important. However, the existence of the wedge of deformed superimposed ice beneath the Pleistocene ice precludes direct measurement of $\xi_{\mathrm{p}}$. Instead, the total thickness of the white ice band, including the fold, was estimated from deformation data from the up-glacier bore hole in Figure 2 (Hooke, 1973[b]) and was measured directly at the glacier surface $75 \mathrm{~m}$ down-glacier from the bore hole (Fig. 4). Using these two thickness measurements and the distance between them, $\xi_{\mathrm{p}}$ was calculated from the path equations. The value obtained was $\xi_{\mathrm{p}}=25 \mathrm{~m}$. $\xi_{\mathrm{I}}$ and $\xi_{2}$ were then selected such that column A took io ooo years to move from $\xi_{2}$ to $\xi_{\mathrm{p}}$ and column B took a similar time to move from $\xi_{\mathrm{I}}$ to $\xi_{2}$. 
To determine $\xi_{1}$ and $\xi_{2}$, we need to know the accumulation and ablation rates, the location of the equilibrium line, and the yield-strength parameter $c$ in Equation (I) (Table II). The equilibrium line is assumed to be at or near the position of maximum horizontal velocity. This position is determined from Holdsworth's (1973, personal communication, December 1973) trilateration-net data, as is $c$. Accumulation and ablation rates are then determined from the equations for $u$ (Table II) using the known value of $u$ and known ice thickness at the equilibrium line. In model 2, the maximum accumulation rate thus obtained, $0.30 \mathrm{~m} /$ year, is in good agreement with the measured submergence velocity at the divide, $0.29 \mathrm{~m} /$ year, and calculated accumulation rates elsewhere in the accumulation zone are in general agreement with rates measured on the trilateration net in $1972-73$.

TABLE II. EQUATIONS For Velocities AND PATHS

Accumulation zone

Accumulation rate

Horizontal velocity

Vertical velocity
Model $I$

$A$ independent of $x$

$$
\begin{aligned}
& u=-\frac{\alpha}{\sqrt{x}}(L-x) \\
& v=-\frac{\alpha y}{2 x^{3 / 2}}(L+x)
\end{aligned}
$$

Time to move from $\xi_{0}$ to $\xi$

$$
\begin{aligned}
t= & \frac{2}{\alpha}\left[\left(\sqrt{ } \xi-\sqrt{ } \xi_{0}\right)+\right. \\
& \left.+\frac{\sqrt{ } L}{2} \ln \left(\frac{\sqrt{ } \xi-\sqrt{ } L}{\sqrt{ } \xi+\sqrt{ } L}\right)\left(\frac{\sqrt{ } \xi_{0}+\sqrt{ } L}{\sqrt{\xi_{0}-\sqrt{ } L}}\right)\right]
\end{aligned}
$$

Path

$$
\eta=\eta_{0} \frac{L-\xi_{0}}{L-\xi}\left(\frac{\xi}{\xi_{0}}\right)^{l}
$$

\section{Model I}

Ablation rate

Horizontal velocity

Vertical velocity

Time to move from $\xi_{0}$ to $\xi$

Path $A_{\mathrm{b}}$ independent of $x$

$$
\begin{gathered}
u=-\alpha^{\prime} \sqrt{ } x \\
v=\frac{\alpha^{\prime} y}{2 \sqrt{ } x} \\
t=\frac{2}{\alpha^{\prime}}\left(\sqrt{ } \xi_{0}-\sqrt{ } \xi\right) \\
\eta=\eta_{0}\left(\frac{\xi_{0}}{\xi}\right)^{t}
\end{gathered}
$$

Model 2

$$
\begin{gathered}
A=A_{\mathrm{m}}\left(\frac{x-x_{\mathrm{e}}}{L-x_{\mathrm{e}}}\right) \\
u=-\frac{\beta}{2 \sqrt{x}}\left[\left(L^{2}-x^{2}\right)-2 x_{\mathrm{e}}(L-x)\right] \\
v=-\frac{\beta y}{4 x^{3 / 2}}\left[\left(L^{2}+3 x^{2}\right)-2 x_{\mathrm{e}}(L+x)\right] \\
t=-\frac{2}{\beta} \int_{\xi_{0}}^{\xi} \frac{\sqrt{x}}{\left(L^{2}-x^{2}\right)-2 x_{\mathrm{e}}(L-x)}
\end{gathered}
$$$$
\eta=\eta_{0} \exp \left[\int_{\xi_{0}}^{\xi} \frac{\left(L^{2}+3 \xi^{2}\right)-2 x_{\mathrm{e}}(L-\xi)}{2 \xi\left[\left(L^{2}-\xi^{2}\right)-2 x_{\mathrm{e}}(L-\xi)\right]} \mathrm{d} \xi\right]
$$

$$
\begin{gathered}
\text { Model } 2 \\
A_{\mathrm{b}}=A_{\mathrm{b}_{\mathrm{m}}}\left(\frac{x_{\mathrm{e}}-x}{x_{\mathrm{e}}}\right) \\
u=-\beta^{\prime} \sqrt{ } x\left(\mathrm{I}-\frac{x}{2 x_{\mathrm{e}}}\right) \\
v=\frac{\beta^{\prime} y \sqrt{ } x}{2}\left(\frac{\mathrm{I}}{x}-\frac{3}{2 x_{\mathrm{e}}}\right) \\
t=\frac{\sqrt{ } 2 x_{\mathrm{e}}}{\beta^{\prime}} \ln \left(\frac{\sqrt{\xi}-\sqrt{ } 2 x_{\mathrm{e}}}{\sqrt{\xi}+\sqrt{ } 2 x_{\mathrm{e}}}\right)\left(\frac{\sqrt{ } \xi_{\mathrm{o}}+\sqrt{ } 2 x_{\mathrm{e}}}{\sqrt{\xi_{\mathrm{o}}-\sqrt{ } 2 x_{\mathrm{e}}}}\right) \\
\eta=\eta_{\mathrm{o}} \frac{2 x_{\mathrm{e}}-\xi_{\mathrm{o}}}{2 x_{\mathrm{e}}-\xi}\left(\frac{\xi_{\mathrm{o}}}{\xi}\right)^{\frac{1}{2}}
\end{gathered}
$$

List OF SYMBOLS

$A=$ Accumulation rate in $\mathrm{m} /$ year.

$A_{\mathrm{m}}=$ Maximum accumulation rate, or accumulation rate at $x=L$.

$A_{\mathrm{b}}=$ Ablation rate in $\mathrm{m} /$ year.

$A_{\mathrm{b}_{\mathrm{m}}}=$ Maximum ablation rate, or ablation rate at $x=0$.

$L=$ Distance from margin to divide (see Fig. 5).

$u, v=$ Velocities in the $x$ and $y$ directions, respectively.

$x, y=$ Coordinate axes: $x$ horizontal and directed up-glacier; $y$ vertical and positive upwards.

$x_{\mathrm{e}}=$ Distance from margin to equilibrium line.

$\alpha=A / \sqrt{ } c$

$\left.\begin{array}{rl}\alpha^{\prime} & =A_{\mathrm{b}} / \sqrt{ } c \\ \beta & =A_{\mathrm{m}} /\left(L-x_{\mathrm{e}}\right) \sqrt{ } c \\ \beta^{\prime} & =A_{\mathrm{b}_{\mathrm{m}}} / \sqrt{ } c\end{array}\right\}$ where $c$ is the constant in the profile equation (Equation (I)).

$\beta^{\prime}=A_{\mathrm{b}_{\mathrm{m}}} / \sqrt{ } c$

$\xi, \eta=x$ and $y$ coordinates respectively of element of ice at time $t$.

$\xi_{0}, \eta_{0}=x$ and $y$ coordinates of element of ice at time $t=0$. 
Once $\xi_{\mathrm{I}}, \xi_{2}$ and $\xi_{\mathrm{p}}$ are determined, we can proceed to calculate $\eta_{\mathrm{pc}}$ and $\eta_{\mathrm{pm}}$. The values of the ratio $\eta_{\mathrm{pc}} / \eta_{\mathrm{pm}}$ thus obtained are $\mathrm{I} .02$ and 0.62 for models $\mathrm{I}$ and 2 , respectively. If the average thickness of the white ice band along the margin is taken to be $13 \mathrm{~m}$ (Fig. 4), its thickness at the center of the ice cap is then calculated to be 13 or $8 \mathrm{~m}$ for the two models, respectively. Model 2 is clearly more realistic so the $8 \mathrm{~m}$ figure is preferred.

The values of $\eta_{\mathrm{pc}} / \eta_{\mathrm{pm}}$ prove to be relatively insensitive to variations in the "travel time". For example, increasing $t$ to $\mathrm{I} 2$ ooo years in model $\mathrm{I}$ increases $\eta_{\mathrm{pc}} / \eta_{\mathrm{pm}}$ by about $\mathrm{I} \%$. Because the calculations are thus insensitive to the exact value of $t$ used, and because the paths (though not the times) are independent of $c, A$ and $A_{\mathrm{b}}$ (Table II), errors in these three quantities have a negligible effect on the result. Furthermore, the assumption of constant shape and balanced budget since the end of the Pleistocene should introduce relatively little error because the columns are close together for a substantial percentage of the "travel time", and both would be affected equally by changes in mass balance and shrinkage of the ice cap at the end of the Pleistocene. Available evidence (Løken and Andrews, I966; Barnett and Holdsworth, 1974; Dyke, unpublished) suggests that the ice cap shrank to close to its present size relatively rapidly.

For comparison with the above calculations, the expected thickness of Pleistocene ice was determined from Philberth and Federer's (I97I) vertical strain-rate model. In this model both the decrease in horizontal velocity with depth and the temperature dependence of the flow law are taken into consideration but the possibility of basal melting is not.

To apply the Philberth and Federer model, we need to know the accumulation rate, the activation energy for creep and the geothermal flux. The accumulation rate is assumed to have been $0.3 \mathrm{~m} /$ year since the end of the Pleistocene. The average ice temperature is about $-5^{\circ} \mathrm{C}$, so the effective activation energy for creep (Hooke and others, 1972) is taken to be $32 \mathrm{kcal} \mathrm{mol}^{-1}\left(134 \mathrm{~kJ} \mathrm{~mol}^{-1}\right)$. The geothermal flux was estimated from temperature measurements in bore holes B4 and D4 (Fig. 4). A correction was made for heat generation in the basal ice by subtracting $\tau_{\mathrm{b}} u / \mathcal{J} K$ from the temperature gradient near the bed (Budd and others, I97I). $\tau_{\mathrm{b}}$ is the basal shear stress calculated from the surface slope and glacier thickness, $u$ is the mean velocity in the $x$ direction, $\mathcal{F}$ is the mechanical equivalent of heat and $K$ is the thermal conductivity of ice. There appears to be a substantial decrease in the geothermal flux

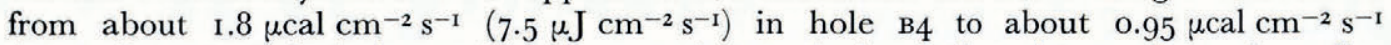
$\left(3.97 \mu \mathrm{J} \mathrm{cm}^{-2} \mathrm{~s}^{-1}\right)$ in hole $\mathrm{D} 4$. The decrease is tentatively attributed to a change in radioactive heat production in the near-surface rocks; the bedrock near $\mathrm{B} 4$ is a quartz-monzonite, which might be expected to contain more $\mathrm{K}, \mathrm{U}$ and $\mathrm{Th}$ than the quartzo-feldspathic gneiss near D4. Preliminary measurements in hole To975 on the trilateration net suggest that the geothermal flux here is essentially the same as in hole D4. Conveniently, the Philberth and Federer model is not sensitive to the exact value of the flux used.

By using these values, and assuming that the top of the white ice band represents a timestratigraphic horizon o ooo years old, we find that there should still be $22-24 \mathrm{~m}$ of Pleistocene ice beneath the center of the ice cap. If the time since the end of the Pleistocene is increased to 12 ooo years, the calculated thickness of Pleistocene ice becomes $20 \mathrm{~m}$. Decreasing the effective activation energy for creep or increasing the thickness of the ice cap increases the expected thickness of Pleistocene ice. The discrepancy between these figures and the $8 \mathrm{~m}$ figure obtained above is perhaps best illustrated by noting that the accumulation rate would have to be increased to I.o m/year in the Philberth and Federer model to obtain agreement between the two approaches.

In view of the uncertainties in these calculations, it would be optimistic to suggest that the difference of $12-14 \mathrm{~m}$ between them is real. In fact, if the thickness of the white ice band on the trilateration net is used as $\eta_{\mathrm{pm}}, \eta_{\mathrm{pc}}$ becomes $24 \mathrm{~m}$ and the discrepancy disappears. However, the difference can be explained if basal melting has occurred, because the Philberth and Federer calculation assumes no basal melting, while in the present approach this assump- 
tion is unnecessary. The rate of basal melting required is about $1.5 \mathrm{~mm} / \mathrm{year}$, which would require about $25 \%$ of the geothermal heat flux. To investigate this possibility, the temperature distribution in a two-dimensional vertical section along the trilateration net was calculated (Fig. 6).
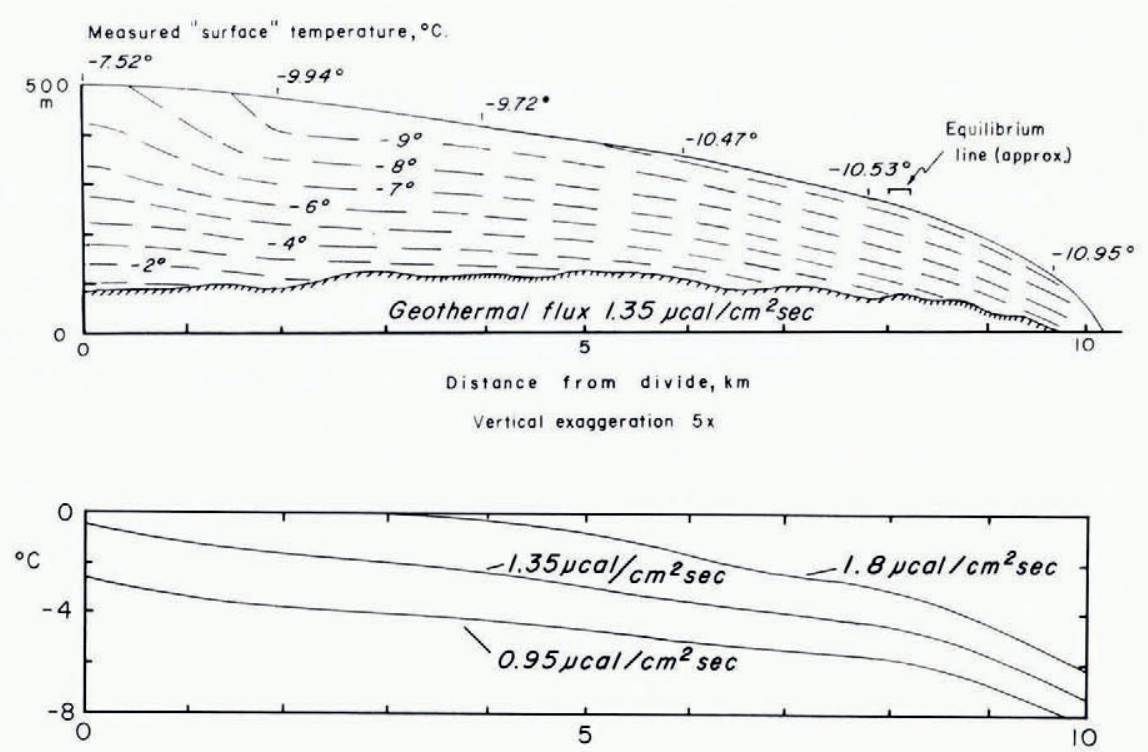

Fig. 6. Temperature distribution in a two-dimensional vertical section extending from the divide to the margin along the trilateration net. "Surface" temperatures measured in $30 \mathrm{~m}$ bore holes in Fuly 1973. Internal temperatures calculated using Budd and others' (I97I) column model. Bed topography from Jones (1972). Surface topography from Holdsworth (1973, personal communication, December 1973). Temperature distribution in upper diagram calculated using geothermal

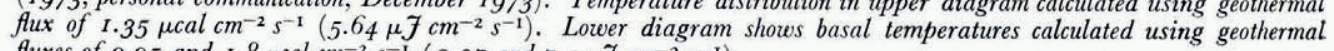

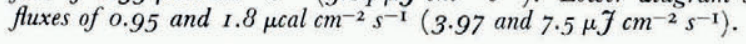

\section{Temperature Distribution}

The temperature distribution was calculated with the use of Budd and others' (I97I) column model. In this model, transverse conduction and convection, longitudinal conduction and non-steady-state changes are neglected, the vertical velocity is assumed to decrease linearly with depth, and internal heat generation is taken into consideration by adding $\tau_{\mathrm{b}} u / \mathcal{F K}$ to the temperature gradient required to conduct the geothermal flux upward into the ice.

To apply this model, we need to know horizontal and vertical velocities, temperatures and longitudinal temperature gradients at the surface, and the geothermal flux. As in the flow-path calculations, the velocities are determined from the equations given in Table II

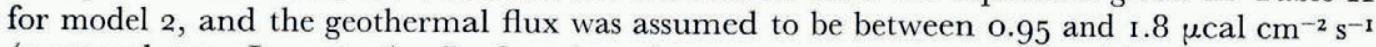
$\left(3.97\right.$ and $\left.7.5 \mu \mathrm{J} \mathrm{cm}^{-2} \mathrm{~s}^{-1}\right)$. Surface $(20 \mathrm{~m})$ temperatures were measured in six $30 \mathrm{~m}$ bore holes in July 1973 (Fig. 6). Longitudinal temperature gradients at the glacier surface, $\mathrm{d} \theta_{\mathrm{s}} / \mathrm{d} x$, are calculated from these temperature data.

It is worth noting that the surface temperature increases up-glacier despite the decrease in air temperature with increasing elevation. This up-glacier increase in surface temperature has a marked effect on the internal temperature distribution. Melt water that percolates down into the snow and refreezes along the snow-ice interface, thus releasing the latent. 
heat of fusion, is responsible for the warming. The rapid increase in temperature within $2 \mathrm{~km}$ of the divide reflects, in addition, the effect of a small amount of permeable firn which allows water to penetrate deeper into the glacier before refreezing. Farther down-glacier, accumulation is usually in the form of superimposed ice.

In the ablation zone the column-model procedure must be modified because the vertical velocity is positive (or upward). The simple column-model equation of Budd and others (1971, p. 63) was integrated once to obtain the temperature gradient as a function of depth, $y$ :

$$
\frac{\mathrm{d} \theta}{\mathrm{d} y}=\exp \left(\alpha y^{2} / 2\right)\left[\gamma_{\mathrm{b}}+\frac{u}{K} \frac{\mathrm{d} \theta_{\mathrm{s}}}{\mathrm{d} x}\left(\frac{\pi}{2 \alpha}\right)^{\frac{1}{2}} \operatorname{erf}\left(\frac{\alpha}{2}\right)^{\frac{1}{2}} y\right]
$$

where $\alpha=A_{\mathrm{b}} / K H$ and $\gamma_{\mathrm{b}}$ is the temperature gradient at the bed. This equation was then integrated numerically to obtain $\theta$ as a function of depth.

When a geothermal flux of $0.95 \mu \mathrm{cal} \mathrm{cm}^{-2} \mathrm{~s}^{-1}\left(3.97 \mu \mathrm{J} \mathrm{cm}^{-2} \mathrm{~s}^{-1}\right)$ is assumed, calculated basal temperatures (Fig. 6) are well below the pressure melting point. This flux would seem to be appropriate for at least the down-glacier end of the trilateration net, and the calculations, therefore, suggest that basal melting may have been negligible along this flow line. However, if fluxes greater than about $\mathrm{I} .4 \mu \mathrm{cal} \mathrm{cm} \mathrm{cm}^{-2} \mathrm{~s}^{-1}\left(5.9 \mu \mathrm{J} \mathrm{cm} \mathrm{cm}^{-2} \mathrm{~s}^{-1}\right)$ are assumed, calculated basal temperatures reach the melting point near the center of the ice cap. Such fluxes appear to be appropriate for the area south-east of the trilateration net, and it is thus tempting to speculate that the south-eastward decrease in thickness of the white ice band is due to basal melting resulting from the increase in geothermal flux in this direction. Holdsworth (1973) calculated basal temperatures along another flow line down the surge lobe (Fig. 4), and found that the pressure-melting temperature was reached at the base along a substantial fraction of this profile also. Holdsworth utilized the Jenssen and Radok ( 1963 ) model in his calculation, and a geothermal flux of about $\mathrm{r} .8 \mu \mathrm{cal} \mathrm{cm} \mathrm{cm}^{-2} \mathrm{~s}^{-1}\left(7.5 \mu \mathrm{J} \mathrm{cm}^{-2} \mathrm{~s}^{-1}\right)$.

\section{Conclusions}

The primary objective of this paper is to present the stable-isotope data which indicate that ice of Pleistocene age is present at the base of the Barnes Ice Cap. The calculations suggest that some Pleistocene ice may have been lost by basal melting. This supports Holdsworth's ( 1973 ) suggestion that basal melting may have triggered a surge of the Barnes Ice Cap. The surge apparently occurred within the past 100 years and resulted in the formation of the present-day Generator Lake (Fig. 4). Temperature calculations indicated that such basal melting is plausible.

\section{Acknowledgements}

This study was supported by the National Science Foundation (Grants GA-I93 Io and GA-42728), the Glaciology Division, Department of Environment, Canada, and the University of Minnesota Graduate School. I am particularly indebted to G. Holdsworth of the Glaciology Division for his co-operation during the investigation and to both G. Holdsworth and A. Judge for permission to use unpublished data. Stable-isotope analyses were done by Teledyne, Inc. The assistance of T. M. Gates of Teledyne, Inc. and of W. Dansgaard in solving some sample-collection problems is gratefully acknowledged. The paper benefited from the critical comments of J. T. Andrews, G. Holdsworth, S. J. Jones, R. M. Koerner and H. E. Wright, Jr.

MS. received zo May 1974 and in revised form 23 September 1975 


\section{REFERENCES}

Barnett, D. M., and Holdsworth, G. 1974. Origin, morphology and chronology of sublacustrine moraines, Generator Lake, Baffin Island, Northwest Territories, Canada. Canadian Fournal of Earth Sciences, Vol. I1, No. 3 , p. $380-408$.

Budd, W. F., and others. 1971. Derived physical characteristics of the Antarctic ice sheet. Mark I, by W.F. Budd, D. Jenssen and $U$. Radok. Melbourne, University of Melbourne, Meteorology Dept. (University of Melbourne. Meteorology Dept., Publication No. 18.)

Dansgaard, W., and Johnsen, S. J. I 969 . A flow model and a time scale for the ice core from Camp Century, Greenland. Journal of Glaciology, Vol. 8, No. 53, p. 215-23.

Dansgaard, W., and others. 1969 . One thousand centuries of climatic record from Camp Century on the Greenland ice sheet, by W. Dansgaard, S. J. Johnsen, J. Møller and C. C. Langway, Jr. Science, Vol. 166, No. 3903, p. $377-8 \mathrm{r}$.

Dyke, A. Unpublished. Deglacial chronology and uplift history: northeastern sector, Laurentide ice sheet. [M.S. thesis, University of Colorado, 1974.]

Epstein, S., and others. 1970. Antarctic ice sheet: stable isotope analyses of Byrd station cores and interhemispheric climatic implications, by S. Epstein, R. P. Sharp and A. J. Gow. Science, Vol. 168, No. 3939, p. $1570-72$.

Holdsworth, G. 1973. Evidence of a surge on Barnes Ice Cap, Baffin Island. Canadian Fournal of Earth Sciences, Vol. 10, No. ro, p. $1565-74$.

Hooke, R. L. I973[a]. Flow near the margin of the Barnes Ice Cap and the development of ice-cored moraines. Geological Society of America. Bulletin, Vol. 84, No. 12, p. 3929-48.

Hooke, R. L. I $973[\mathrm{~b}]$. Structure and flow in the margin of the Barnes Ice Cap, Baffin Island, N.W.T., Canada. Journal of Glaciology, Vol. 12, No. 66, p. 423-38.

Hooke, R. L., and others. 1972. Creep of ice containing dispersed fine sand, by R. L. Hooke, B. B. Dahlin and M. T. Kauper. Fournal of Glaciology, Vol. 1 i, No. 63, p. 327-36.

Hudleston, P. J. In press. Recumbent folding in basal ice of the Barnes Ice Cap, Baffin Island, Northwest Territories, Canada.

Jenssen, D., and Radok, U. 1963. Heat conduction in thinning ice sheets. Fournal of Glaciology, Vol. 4, No. 34, p. $387-97$.

Jones, S. J. I972. Radio depth-sounding on Meighen and Barnes ice caps, Arctic Canada. Ottawa, Environment Canada. Water Resources Branch. Inland Waters Directorate. (Scientific Series, No. 25.)

Koerner, R. M., and others. 1973. $\delta^{18} \mathrm{O}$ profile in ice formed between the equilibrium and firn lines, [by] R. M. Koerner, W. S. B. Paterson, H. R. Krouse. Nature, Physical Science, Vol. 245, No. I48, p. I 37-40.

Løken, O. H., and Andrews, J. T. 1966. Glaciology and chronology of fluctuations of the ice margin at the south end of the Barnes Ice Cap, Baffin Island, N.W.T. Geographical Bulletin (Ottawa), Vol. 8, No. 4, p. 34 I-59.

Nielsen, L. E., and Stockton, F. D. 1956. Flow patterns in glacier ice. Journal of Applied Physics, Vol. 27 , No. 5, p. $448-53$.

Nye, J. F. 195I. The flow of glaciers and ice-sheets as a problem in plasticity. Proceedings of the Royal Society of London, Ser. A, Vol. 207, No. I091, p. 554-72.

Philberth, K., and Federer, B. 1971. On the temperature profile and the age profile in the central part of cold ice sheets. Journal of Glaciology, Vol. Io, No. 58, p. $3^{-1} 4$. 